\section{Trends and Directions in RA Education}

\section{Stephanie H. Anderson \\ Guest Editor, Barry Trott}

\begin{abstract}
Stephanie H. Anderson is the Assistant Director for Public Service at the Darien (CT) Library. This article is excerpted from her final paper from her independent study of RA education, undertaken during her MLIS studies at Syracuse University.
\end{abstract}

Correspondence to this column should be addressed to Laurel Tarulli, Librarian and Information Services Manager, Sacred Heart School of Halifax; email: laureltarulli@yahoo.com; email: laureltarulli@yahoo.com.
The last two issues of the Readers' Advisory (RA) column have featured thoughtful, though somewhat different, views of the future of services to readers in public libraries. Duncan Smith and Bill Crowley share an understanding of the value and importance of RA services, if disagreeing on the steps to ensure the continued success of those services. Here, Stephanie Anderson looks at a topic that lays the foundation for the future of RA practice: RA education.-Editor

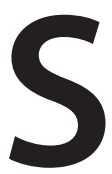

ince its beginnings, there has been confusion over what readers' advisory (RA) encompasses, how it should be practiced, and how it should be taught. Adult RA is an important part of modern public library service, but it is not a consistent part of modern library education or training. In public libraries, adult RA is the subject of an increasing amount of professional attention. However, academic researchers, who have never had much interest in RA to begin with, have not shared this growing interest. As a result, a 2013 Library Journal survey found that although all libraries they surveyed offered RA, 42 percent respondents took no RA coursework in their ML(I)S programs, and 23 percent reported no RA education opportunities at their library. ${ }^{1}$ This disconnect has far-reaching implications for the ability of public libraries to adequately serve adult patrons.

RA is important for the role it plays in reading in the lives of adult patrons, and reading is important in patrons' lives for many reasons. Dali asserts that "our grounds for RA and reading advocacy should include coping, relaxation, personal growth, spiritual maturation, adaptation, and adjustment, all of which contribute to the reader's well-being, mental stability, and improved physical health." Despite these numerous benefits, education for this crucial skill remains patchy, even though, as Stover writes, "Readers' advisory, one of the most popular and fastest growing services in libraries, requires time and training to do well." The sad truth is, as Crowley notes, "effective RA is simply not a priority in America's public libraries or else RA training would be both mandatory and regularly provided." ${ }^{.4}$ In addition to inconsistent levels of training, academics continue to push for new approaches to RA, but these theories are largely unknown by practitioners, who continue to focus on an appeal-based and material-centered approach. Moving forward, an improved connection between practitioners in public libraries and academics in LIS programs, as well as a profession-wide reevaluation of the importance of RA to adult public library patrons, could finally lead RA education in a direction that will create meaningful change in the field 


\section{READERS' ADVISORY}

and for adult library patrons across the country, but these changes must happen soon if they are to happen at all.

\section{RECENT TRENDS IN RA EDUCATION}

Several exciting trends in RA practice have developed in the past decade, each reflecting larger changes in how libraries serve their communities, and each requiring new instruction in RA, even for long-time practitioners. One of the biggest trends in RA education has been catalyzed by experimentation with RA online, which has necessitated not only teaching new skills to readers' advisors, but also often enlisting new staff to be trained in RA to provide the service. Many recent conference presentations-a common form of education for RA practitioners-have focused on moving RA online, especially on social media. ${ }^{5}$ Despite focused professional attention, this trend is still in early stages; Burke and Strothmann recently found that although librarians who have experimented with online RA receive positive feedback from patrons and improve the quality of their RA service, "libraries that offer robust online RA services remain a minority," with only 17.6 percent of public libraries in their study's sample having a RA page on their website. ${ }^{6}$ A prominent recent example is the My Librarian program, launched by the Multnomah County Library after extended research, a successful initiative to bridge the gap between online patrons and readers' advisors. House writes that "My Librarian takes a big step toward humanizing the online library experience."' MCL is a system with a strong commitment to RA education, and has a full roster of internal practitioner-led education that supports the My Librarian program, according to Reader Services Librarian Alison Kastner. ${ }^{8}$ While an in-house RA 101 class is required for all Information Services staff at MCL, they also offer a full "menu" of other RA classes to their staff. As in MCL, initiatives to bring RA online are usually developed by practitioners, and all education for them is created by the library system. In addition, education around RA online cannot just address the practice of RA but also has to address the technological skills needed to move RA online, which often presents an equal barrier. Wyatt's enthusiasm for reading maps demonstrates another approach to finding new ways to represent RA online, and faces similar educational barriers. ${ }^{9}$ This trend is likely to continue, driven by the practitioners who seek to add it to their library's services; however, in the absence of formal training, it may continue to be a grassroots effort determined by the educational resources of the library hoping to expand service online.

Another larger library trend driving changes in RA education is lending e-books in the library. Changes in the ways patrons read have led many readers' advisors to add e-book troubleshooting to their skill set, as well as provided a new opportunity to librarians specializing in tech help to practice RA. Many readers' advisors begin doing RA with the digital collection while walking a patron through the process of downloading an e-book, and others have found an increase in questions from patrons about which devices and formats they recommend. As Dunneback explains, "With the need of an intermediary technology on which to read the story, e-books present a fascinating area of advisory for librarians. We need to be able to be advisors of technology in addition to content."10 She suggests that "readers' advisory trainers should begin including discussions of the technology in continuing education sessions even if their library does not currently offer e-books as part of the collection." Technology, especially around lending library ebooks, continues to change at a rapid pace and often needs to be taught to librarians via other practitioners, making this an important trend for RA education and one that currently requires continuous attention. As Wyatt writes, "If we can experiment with the forms in which we offer RA service, we can take RA work even further."1l This can include both new forms of RA as well as new forms of materials in which patrons are interested, with both experiments requiring additional RA education, even for long-time practitioners.

Trends in practice such as these generally originate in public libraries and migrate to other practitioners, often via RA educators presenting at conferences and writing articles. In fact, many RA practitioners are also educators-some as adjunct professors, but many more at professional conferences, library training sessions, and online webinars. One of the most exciting trends in RA education is the ongoing sharing of ideas in professional circles, a trend which can be seen in the continued growth of practitioner-led RA education, especially online. Dali notes with approval that "The rich repository of intellectual discourse and practical experience in appealbased RA created by [practitioners] will benefit generations of practitioners for years to come." ${ }^{\text {"2 }}$ As Orr notes, this trend is important because in addition to "the gaps in LIS education, what about keeping up with the field once you've graduated?"13 However, it is discouraging that Dali later notes that "Public librarians are not sufficiently encouraged to engage in empirical research and to commit to publishing," because this means that these trends in practice are unlikely to be formalized or critically examined. ${ }^{14}$ It also means that most RA education is limited in its reach to those with the time and resources to access conferences, articles, and webinars. Though the trend has been for decades that practitioners in public libraries create and provide RA education, this trend has not translated to additional research or interest from LIS scholars. In addition, the few academics who are interested in RA appear to have a different set of concerns for adult RA, and are separately following a different set of trends-particularly trends in theory.

For example, perhaps the most marked trend in thinking about RA theory among LIS scholars is a push to move beyond the current standard of Saricks' appeal factors as the primary tool for RA. ${ }^{15}$ This represents a substantial break from RA as it is currently taught. Beard and Thi-Beard find appeal factors to be limited in utility, based on recent research, writing that "there is a strange faith that, if we find better ways to describe the object, we can more easily connect the object to patron. Such efforts are important; being able to describe a novel in terms of its genre, setting, characters, and plots is an important first step in RA. But research in literacy challenges 
the idea that readers select a book based on its features."16 Crowley agrees, writing, "The use of new technologies aside, the quarter-century effort to transform RA tacit knowledge into theoretical guidance for practitioners in the tradition pioneered by Saricks and Brown has more or less reached its practical limits. ${ }^{\prime \prime 7}$ Dali further echoes the sentiment, declaring that "there is a need for a drastically new definition of appeal and a radically different approach to appeal in the practice and teaching of RA," and even that making a distinction between genre conventions and genre appeals "appears fairly artificial and therefore should be abandoned."18 Begum's work on the importance of escapist reading further supports the idea that adherence to genre and appeal might limit RA education. ${ }^{19}$ She writes, "Training for readers' advisors to better aid escapist readers means rethinking traditional formats of advisory. One example may be to forego strict focus on genre lists or straightforward author/title knowledge." As appeal factors are a cornerstone of many RA classes and texts, and have been for almost thirty years, these assertions represent a substantial break from RA as it is currently taught.

Curiously, despite being quite different from what almost all readers' advisors have learned in the last twenty-five years, this trend in theory has barely reached most of those who are teaching it. So although there is a growing consensus that new work needs to be done in this area, it is only among a few researchers in the academic space. Practitioners, and some LIS instructors, still rely heavily on appeal factors to teach RA. A review of available syllabi for RA courses taught in MLIS programs shows that almost all courses are structured around review of different genres and appeal factors. ${ }^{20}$ Indeed, by contrast to the growing academic discontent with appeal factors, much of the sharing seen in the trend of practitioner-initiated sharing of RA knowledge revolves around improving accuracy of appeal terms and the understanding that readers' advisors have of them. Crowley observes this gap and writes that "one indicator of a stalled RA paradigm is the lack of theoretical upgrades on fundamental issues."21 Though the theory is being researched and debated in a limited context, it has had almost no affect on RA education. This is a confusing set of trends; it's no surprise that Trott notes, "The continued success of readers' advisory services depends on the continued cooperation between practitioners in the field and researchers and theorists in the academy. At times these groups have progressed on parallel courses that do not intersect, resulting in loss of opportunities for useful and fruitful collaboration."22 In fact, these groups appear to be progressing on courses that are heading in opposite directions, which has negative implications for the future of RA education.

\section{THE FUTURE DIRECTION OF RA EDUCATION}

Ultimately, the goal of RA education is to empower librarians to provide excellent RA service in their libraries. By that standard, RA education has much work to do. May et al., in their 2000 study of the Nassau Library System, found that there was no formal RA protocol in the libraries they visited, writing that "a nonmethodical, informal, and serendipitous response was the norm to a patron's request for a "good read."'23 Shearer found the same results in his study of North Carolina public libraries, and Orr, who uses a similar assignment with her RA students, writes that "the recent results show that libraries still need a lot of help in this area." ${ }^{24}$ These findings suggest that the current method and trends-minimal academic involvement in RA, combined with education that is largely dependent on the influence of enthusiastic practitioners-has limited efficacy in improving the practice of RA. If the contemporary approach to RA education has led to inconsistent RA service to adults, then an improvement in the level of service will depend on a future in which our profession's approach to RA education changes. For RA education to evolve to that level in the future, RA must be recognized as a core skill of public librarianship with clearly defined roles and best practices, additional research must be undertaken to better understand which RA tactics are most effective, as well as the motivations and choices of adult readers, and the ever-present gap between academia and practitioners must be closed.

Though the future of RA education is about as easy to predict as the future of libraries, it is clear that something must change for RA service to improve in the future, and that change must begin in how RA is taught and regarded. Though Dilevko and Magowan's views on RA differ from mainstream opinion, most would agree with their observation that

the kind of readers' advisory service that each librarian chooses to offer-or feels compelled to offer—speaks to the vision of librarianship that is dominant at a specific public library or is present in a librarian's mind, or a commingling of the two. And so, while each readers' advisory transaction is a discrete event given form and substance by the proximate factors impinging upon it, at a theoretical level it can be constructed as a staging ground for a debate between competing models of public librarianship. ${ }^{25}$

In addition to competing models of public librarianship, RA is also caught between competing theories about the importance of pleasure reading and popular materials for adults. While RA has moved beyond the years of the "fiction problem," there is continued disagreement about the role of the public library in providing leisure reading for adults. ${ }^{26} \mathrm{As}$ Crowley proposes, "The true problem for RA lies in the reality that practitioner perceptions of its value and relevance are not often shared by library directors and funders." ${ }^{27}$ Regan's 1973 statement still rings true: "The public image of most reader's advisers, as of the library itself, is burdened by ideals of the intellectual and spiritual worth of better reading, rather than the simple enjoyment which can be derived." 28 Whatever the future direction of RA education, it will be difficult for any forward movement to take place without 


\section{READERS' ADVISORY}

a greater agreement within the profession about whether pleasure reading is indeed a core service of libraries, and thus whether the skills that librarians develop to provide that service are worthy of formal pedagogy and research.

The first step in the continued development of RA and RA education is to develop a permanent belief, especially among public library administrators and boards of trustees, that RA is a core part of public library services. Without consistent professional demand for librarians trained in RA, there is little motivation for librarians without a natural inclination toward RA to provide these skills, nor for libraries to invest in RA education. Although the 2013 Library Journal survey found that 100 percent of surveyed librarians provided RA in their libraries, this has not translated to the type of support other core library services receive- for example, only 9 percent of libraries surveyed had full-time readers' advisors on staff. When compared to the institutional support adult reference service generally fosters, this is striking, especially considering Beard and Thi-Beard point that "RA is an organic extension of the array of reference services already offered in the library. Maybe equally important for the library as a social institution, RA establishes a connection between patron and library." ${ }^{29}$ Crowley agrees that a clear role for RA is important, and cautions that as librarians create this role, RA needs to be built into library services, rather than set apart from them. He writes, "Readers advisory must: (a) be justified by its positive effects on the entire library program; and (b) build a building-wide or organization-wide constituency." ${ }^{30}$ Trott also writes about the importance of integrating RA into core services, as well as how education is central to this change, explaining, "Changing the false dichotomy that separates information-based questions from readingcentered questions in library public service can be addressed at all levels in the profession, from library school curricula to the day-to-day library practice." ${ }^{31}$ One challenge to this change is that at the moment, whether taught by professors or practitioners, there is no agreement about what the role of a readers' advisor is, what the professional status of those offering RA services should be, nor a standard curriculum or institution from which the many forms of RA education can draw. Smith writes that "First, the profession needs to identify and define the nature of the readers' advisory role. Library staff members need a map of readers' advisory practice." ${ }^{32}$ A related concern is whether RA should be defined as a professional task, which Crowley identifies as a serious concern and Dilevko and Magowan see as related to developments like the NoveList database and Genreflecting, writing that these services allow "library administrators to think that such service can be delivered just as efficiently by lowersalaried paraprofessionals as by higher-salaried librarians." ${ }^{33}$ In response to this viewpoint, and that of Crowley, Smith writes that "readers' advisory service will only be professionalized when it is consistently and effectively delivered. We should not be so concerned with who delivers the service but the quality of the service that is being delivered." ${ }^{\text {34 }}$ Settling the question of the role of the readers' advisor, and what a readers' advisor is required to know, may bring clarity to defining the necessary education level and professional qualifications needed for that position.

However, even clarifying the role of the readers' advisor and best practices for RA will not be enough to elevate RA education; there will still be crucial gaps in the research that is needed to provide useful information about adult readers and their behavior. The paucity of this research is a result of decades of professional disinterest, as Dawson and Van Fleet note, "Given the value of reading and the public's demand, it is disturbing that the library and information science profession has not more widely and enthusiastically embraced the readers' advisory function." ${ }^{35}$ Theories and research that support RA must be reexamined and updated to broaden what is taught to librarians. In some cases, the research is there, but it is not yet regularly included in education of RA. For example, reading studies have validated the gut instinct of many librarians that leisure reading and escapist reading are important for the mental health and personal development of adult readers, a crucial piece of research for RA advocates. ${ }^{36}$ Begum found that "the transformative nature of leisure reading is such that it can be considered by many a means of maintaining humanity and a sense of self in sometimes uncertain and dangerous settings. ${ }^{37}$ The implications of continued work around the importance and use of reading in adult lives could mean more changes for current RA and how it is taught, as well as who learns it. However, because reading and RA have not been priorities for LIS studies, there is a gap between LIS and other disciplines doing this work, with an even larger gap between practitioners in public libraries and research into adult readers. Beard and Thi-Beard note that "more work has yet to be done to integrate contemporary research on literacy with contemporary readers' services," but this contemporary research is often not taking place in LIS departments. ${ }^{38}$ Ross, McKetchnie and Rothbauer observe that

in the past fifteen years or so, a great deal of research has been published about reading, reader response, audiences, genres, the value of popular culture, book clubs, communities of readers who meet face-to-face or virtually to talk about books, and the role of libraries in promoting literacy and reading. The literature is scattered and fragmentary, however, published variously in scholarly journals and monographs in education, cultural studies, media studies, and library and information science. ${ }^{39}$

Much of the research readers' advisors would like to undertake or use to improve their services has already been started in other fields; in the future, RA educators could collaborate with researchers in those fields to teach RA effectively, bypassing LIS researchers. As Orr observes, "Research in reading for pleasure has developed into a robust field without us." ${ }^{\text {"40 }}$ Alternately, Crowley offers several intriguing opportunities for LIS to better embrace RA studies, including 
partnerships and funding with state library associations and placing pressure on the ALA to require such coursework to fulfill accreditation requirements, all of which would help close this gap. ${ }^{41}$ As Crowley writes, "The RA community has reached the point where it has become necessary to draw on the research of other fields to determine (1) its relevance to RA and (2) how best it can be turned into the "new RA knowledge' necessary to develop innovative and energizing mental tools for use by the RA advisor in her or his future interactions with readers, viewers, and listeners. "리 Dali also makes note of this necessity. She suggests that "what [reading advocates and pioneers like Chelton, Saricks, Smith, and others] built has guided RA for over 30 years, and we are still basking in their glory and using their ideas without contributing much of our own except the inevitable: going online. It is about time we took RA to the next level and add to the foundation that they had built by turning RA into an embedded community service and a reader-centered subject of scholarly inquiry and graduate LIS education." ${ }^{23}$ This call to action animates what one future for RA education could be, with additional research and support for RA.

By far, the greatest challenge facing the development of RA education at this point is the gap between RA theory and practice; between the academy and practitioners. RA is by no means the only subject in LIS with this problem, but it's a particular issue for RA given the relatively small number of people working in the field. There is no organization or journal devoted exclusively to RA, and Moyer points out that "with no specific journal addressing this need, librarians who want to keep up-to date with fiction studies and research on readers' advisory services must use electronic databases such as Library and Information Science Abstracts and Library Literature and Information Science. Unfortunately, this is not an easy task." ${ }^{24}$ Not only is this research difficult for many practitioners to access, relevant research is still incomplete in many places. For example, according to Dali, "Sorely missing is LIS research into the contemporary reading practices of adults, including seniors, immigrant and ethnic communities, marginalized readers (e.g., prisoners), and readers with print disabilities. ${ }^{145}$ Orr believes that part of the issue is that RA research is still happening too infrequently, writing that "while there are an increasing number of papers being published in the RA field today, we need more, especially those including solid research." ${ }^{146}$ This low access and missing scholarship places several barriers between the present and the future of RA education, compounded by Wright's observation: "Why don't librarians read more professional literature? Out of many reasons not to, a few may suffice: it's boring, we're busy, and life is short." ${ }^{\prime 47}$ Wiegand posits that beyond the effect on RA service, this lack of literature and access to it is also a problem for public libraries seeking to demonstrate their value to stakeholders because at this point, "unfortunately, librarians have little knowledge of why people read what they do. As a result, they lack a deeper understanding of how libraries already serve readers, and they miss evidence that they could use to convince state legislatures and other sources of financial support that spending money on stories is important."48 The challenge of engaging LIS researchers more deeply in research related to RA is not just a problem for RA education-it is also a problem for the service and the readers it supports.

This gap is unlikely to close without sustained effort. Van Fleet warns that "students who are engaged and excited by the theories and concepts to which they are introduced in readers' advisory or adult services classes and who decide to pursue doctorates may find that they are hard-pressed to find a doctoral program in a school of library and information science that meshes well with their intended area of study and research."49 Orr suggests that changes to who provides RA education in MLIS programs could alter this in the future, writing that "obviously, many readers' advisors would love it if more library school educators would take up the torch. But another solution might be for practicing RA librarians to continue to share their knowledge as adjuncts, but to also consider obtaining a Ph.D with the goal of becoming full time professors." ${ }^{50}$ Currently, however, most publications on RA are in professional journals, on practical advances in RA, and that is where most practitioners have influence. According to Moyer, "The largest area of publication [about readers' advisory] is in general readers' advisory services. These are about serving the reading public, readers' advisory tools, readers' advisory Websites, and readers' advisory services in the public library. Most of these publications are written by and for staff and librarians who regularly work with readers and few are about research projects. ${ }^{\text {II }}$ Whether the gap between the interests and writing of practitioners and the research of academics can be bridged-and truly, whether either group wants it to-has tremendous implications for the future direction of RA and RA education.

Despite continued confusion over the work of RA and lack of research, there are nevertheless attempts to develop RA education in new directions, and these provide a tantalizing look at what RA education could provide with proper acknowledgement and support. For example, based on her research, Dali has proposed a new method and approach, called the Single Questions aimed at Inducing Narrative method (SQUIN). ${ }^{52}$ Using SQUIN, a readers' advisor would ask one question that would elicit a longer response from the patron, up to fifteen minutes, rather than the back-andforth of a traditional RA interview. In 2013, she wrote, "The SQUIN method can also serve as a training and educational tool for readers' advisors, who should become accustomed to and skilled at listening to stories and narratives." The SQUIN method, which has not yet been embraced by practitioners because most are unaware of it, introduces a new way to practice and teach RA in public libraries, as well a potential answer to the growing understanding that appeal factors are no longer a sufficient basis for RA education. It offers an intriguing possibility as to what is possible for the future of RA education, if only the challenges described above can be surmounted. The future direction of RA education can be 
more than additional roundtables and occasional articlesit can be librarians at the forefront of changing how adult readers connect with literature, and it can be more readers' advisors across the country matching even more adult readers with the right book at the right time. It can be every adult library patron having access to a high-quality service that they desire, use, and deserve.

\section{CONCLUSION}

Haunting any possible future for RA education is Moyer and Weech's observation that there is "an apparent 40-year cycle in the visibility of perceived importance of adult readers' advisory services in libraries." ${ }^{\prime 53}$ By that measure, if the current wave of perceived importance can be tracked back to the 1980s, here in 2016, we are fewer than ten years from the next dark age in adult RA and RA education. ${ }^{54}$ This potential for decline is compounded by Orr's observation that "the graying of the profession [is] affecting both practitioners and professors," meaning that if younger librarians and academics are not taught about RA, it will be even easier for the last few decades of work to be lost. ${ }^{55}$ Large-scale changes need to happen, starting with improvements in education at all levels, to break this cycle and instead build on what has been accomplished. Without serious attention to this issue, the work done in RA education since the 1980s risks being lost and, perhaps, rediscovered decades from now.

The potential of RA to positively affect readers and library users across the United States is incredible, but only if RA education can meet the challenge, in both practitioner and academic communities. What's more, changes to RA education in the future need to work for multiple constituencies. As Smith notes, "We can't be focused just on people who are learning and entering the profession. It also has to be accessible to people in the field. ${ }^{.56}$ The urgency for a new future for RA education that pushes RA further than the current trends goes beyond the needs of readers' advisors-it is driven by the needs of adult library patrons. As Hollands and Moyer note, "Though the form in which people receive advice varies tremendously, access to some kind of intelligent suggestion about what one might read next is at an all-time high. The long-term success of readers' advisory, however, remains in the balance." ${ }^{57}$ Adult public library patrons clearly desire RA services and access to the books readers' advisors recommend, and RA education in all its forms needs to step up to allow public librarians to meet this need to the best of our abilities.

\section{References and Notes}

1. Library Journal, "Readers' Advisory Services in Public Libraries: Responses from 694 Public Libraries Surveyed in November 2013," Library Journal, 2013, http://lj.libraryjournal.com/ downloads/2013-readers-advisory-services-in-public-libraries.

2. Keren Dali, "Readers' Advisory: Can We Take It to the Next
Level?" Library Review 64, no. 4/5 (2015): 386.

3. Kaite Mediatore Stover, "Working Without a Net: Readers' Advisory in the Small Public Library," Reference \& User Services Quarterly 45, no. 2 (2005): 122-25.

4. Bill Crowley, "Differing Mental Models and the Futures of Libraries, Librarians, and Readers' Advisory," Reference \& User Services Quarterly 55, no. 2 (2015): 94.

5. For examples, see Karen Pundsack, "Moving Readers' Advisory Online," Public Libraries Online, 2014, http://publiclibrarieson line.org/2014/09/moving-readers-advisory-online.

6. Susan K. Burke and Molly Strothmann, "Adult Readers' Advisory Services through Public Library Websites," Reference \& User Services Quarterly 55, no. 2 (2015): 141.

7. Kelly House, "Your Own Personal Librarian: Multnomah County Library Allows Patrons to Pick Professional Book Advisors Online," Oregon Live, 2014, www.oregonlive.com/portland/ index.ssf/2014/04/your_own_personal_librarian_mu.html.

8. Alison Kastner, email message to author, April 7, 2015. See also the presentation at Multnomah County Library, "My Librarian: Personalization and the Future of Reader's Services," 2015, https://prezi.com/py7wucylzs47/my-librarian-personalization -and-the-future-of-readers-ser.

9. Neal Wyatt, "Redefining RA: Reading Maps Remake RA," Library Journal, 2006, http://lj.libraryjournal.com/2006/11/ljar chives/lj-series-redefining-ra-reading-maps-remake-ra.

10. Katie Dunneback, "E-books and Readers' Advisory," Reference \& User Services Quarterly 50, no. 4 (2011): 325-29.

11. Neal Wyatt, "Redefining RA."

12. Keren Dali, "Hearing Stories, Not Keywords: Teach Contextual Readers' Advisory," Reference Services Review 4, no. 3 (2013): 474-502.

13. Cindy Orr, "Dynamics of Reader's Advisory Education: How Far Can We Go?" Readers' Advisor News, 2009, http://readersadvisor online.com/ranews/sep2009/orr.html.

14. Keren Dali, "Readers' Advisory," 374.

15. Joyce G. Saricks, Readers' Advisory Service in the Public Library, 3rd ed. (Chicago: American Library Association, 2005). As articulated in the first edition of this book, published in 1989, and subsequent editions, appeal factors have come to be one of the cornerstones of the body of knowledge around adult readers' advisory.

16. David Beard and Kate Vo Thi-Beard, "Rethinking the Book: New Theories for Readers' Advisory," Reference \& User Services Quarterly 47 , no. 4 (2008): 331-35.

17. Bill Crowley, "Time to Rethink Readers' Advisory Education?" Public Libraries 5, no. 4 (2014): 37-43.

18. Dali, "Hearing Stories, Not Keywords."

19. Soheli Begum, "Readers' Advisory and Underestimated Roles of Escapist Reading," Library Review 60, no. 9 (2011): 738-47.

20. According to a review of approximately twenty RA syllabi from MLIS courses undertaken in Spring 2015.

21. Crowley, "Differing Mental Models," 95.

22. Barry Trott, "Reference, Readers' Advisory, and Relevance," The Reference Librarian 53, no. 1 (2011): 60-66.

23. Anne K. May, Elizabeth Olesh, Anne Weinlich Miltenberg, and Catherine Patricia Lackner, "A Look at Readers' Advisory Services," Library Journal 125, no. 15 (2000): 40-43.

24. Kenneth D. Shearer, "The Nature of the Readers' Advisory Transaction in Adult Reading," in Guiding the Reader to the Next Book, edited by Kenneth D. Shearer (New York: Neal-Schuman), 1-20; Cindy Orr, Crash Course in Readers' Advisory (Santa Barbara, CA: Libraries Unlimited, 2015).

25. Juris Dilevko and Candice F. C. Magowan, Readers' Advisory Service in North American Public Libraries, 1870-2005: A History and Critical Analysis (Jefferson, NC: McFarland, 2007).

26. As Ross explains, "The 'fiction problem' was that people liked 
fiction, while many librarians regarded fiction-reading as little better than pool-playing." Catherine Sheldrick Ross, "Readers' Advisory Service: New Directions," RQ 30, no. 4 (1991): 503-18.

27. Crowley, "Differing Mental Models," 94.

28. Lee Regan, "A Public Library Survey: Status of Reader's Advisory Service," RQ 12, no. 3 (1973): 227-33.

29. Beard and Thi-Beard, "Rethinking the Book."

30. Bill Crowley, "Rediscovering the History of Readers Advisory Service," Public Libraries 44, no. 1 (2005): 37-41.

31. Trott, "Reference, Readers' Advisory, and Relevance."

32. Duncan Smith, "Talking with Readers: A Competency Based Approach to Readers' Advisory Service," Reference \& User Services Quarterly 40, no. 2 (2000): 135-42.

33. Crowley, "Time to Rethink Readers' Advisory Education?"; Dilevko and Magowan, Readers' Advisory Service in North American Public Libraries, 1870-2005. Ironically, practitioners developed these services out of necessity, as there were almost no educational resources for readers' advisors, given that less than half of MLIS programs offer readers' advisory coursework.

34. Duncan Smith, "Talking With Readers: A Competency Based Approach to Readers' Advisory Service," Reference \& User Services Quarterly 40, no. 2 (2000): 135-42.

35. Alma Dawson and Connie Van Fleet, "The Future of Readers' Advisory in a Multicultural Society," in The Readers' Advisor's Companion, edited by Kenneth D. Shearer and Robert Bergin (Englewood, CO: Libraries Unlimited, 2001), 247-38.

36. As Ross, McKechnie, and Rothbauer observe, "Library staff, in particular, have a gut feeling that reading is a Good Thing and that libraries should play-and do play-a vital role in promoting it. But library staff members often find it hard to explain why." Catherine Sheldrick Ross, Lynne E. F. McKechnie, and Paulette M. Rothbauer, Reading Matters: What the Research Reveals About Reading, Libraries, and Community (Westport, CT: Libraries Unlimited, 2006), ix.

37. Begum, "Readers' Advisory and Underestimated Roles."

38. Beard and Thi-Beard, "Rethinking the Book."

39. Catherine Sheldrick Ross, Lynne E. F. McKechnie, and Paulette M. Rothbauer, Reading Matters: What the Research Reveals About Reading, Libraries, and Community (Westport, CT: Libraries Unlimited, 2006), ix.

40. Orr, Crash Course in Readers' Advisory.

41. Bill Crowley, "Taught at the University on a Higher Plane Than Elsewhere': The Graduate Education of Readers' Advisors," in
The Readers' Advisor's Companion, edited by Kenneth D. Shearer and Robert Bergin (Englewood, CO: Libraries Unlimited, 2001), $27-58$.

42. Crowley, "Time to Rethink Readers' Advisory Education?"

43. Dali, "Readers' Advisory," 376.

44. Moyer, "Learning From Leisure Reading."

45. Keren Dali, "How We Missed the Boat: Reading Scholarship and the Field of LIS," New Library World 116, no. 9/10 (2015): 480.

46. Orr, Crash Course in Readers' Advisory.

47. David Wright, "Readers' Advisory Interview," in Research-Based Readers' Advisory, edited by Jessica E. Moyer (Chicago: ALA Editions, 2008), 154-71.

48. Wayne A. Wiegand, "Missing the Real Story: Where Library and Information Science Fails the Library Profession," in The Readers' Advisor's Companion, editd by Kenneth D. Shearer and Robert Bergin (Englewood, CO: Libraries Unlimited, 2001): 7-14.

49. Connie Van Fleet, "Education for Readers' Advisory Service in Library and Information Science Programs: Challenges and Opportunities," Reference \& User Services Quarterly 47, no. 3 (2008): 224-29.

50. Orr, "Dynamics of Reader's Advisory Education."

51. Jessica E. Moyer, "Learning From Leisure Reading: A Study of Adult Public Library Patrons," Reference \& User Services Quarterly 46, no. 4 (2007): 66-79.

52. Dali, "Hearing Stories, Not Keywords."

53. Jessica E. Moyer and Terry L. Weech, "The Education of Public Librarians to Serve Leisure Readers in the United States, Canada and Europe," New Library World 106, no. 1/2 (2005): 67-79.

54. Barry Trott makes this case in "Building on a Firm Foundation": "The 1980s saw three major events that re-established the value of working with readers: the publication of the first edition of Genreflecting under the editorship of Betty Rosenberg (1982); the establishment of the Chicago-area Adult Reading Roundtable (ARRT) (1984); and the publication of the first edition of Readers' Advisory Service in the Public Library by Joyce Saricks and Nancy Brown (1989)" (Reference and User Services Quarterly 48, no. 2 (2008): 132-35).

55. Cindy Orr, "Dynamics of Reader's Advisory Education."

56. Duncan Smith, email message to author, March 23, 2015.

57. Neil Hollands and Jessica E. Moyer, "The Future of Readers' Advisory," in Research-Based Readers' Advisory, edited by Jessica E. Moyer (Chicago: ALA Editions, 2008), 242-60. 